\title{
A Place at the Table? Parliamentary Committees, Witnesses and the Scrutiny of Government Actions and Legislation
}

\author{
Hugh Bochel* and Anouk Berthier** \\ *School of Social and Political Sciences, University of Lincoln \\ E-mail: hboche/@lincoln.ac.uk \\ **Scottish Parliament Information Centre, Scottish Parliament \\ E-mail: Anouk.Berthier@parliament.scot
}

Issues of diversity in elected bodies have been highlighted in recent years, both with regard to elected representatives themselves, and, more recently, in respect of the treatment of those working in such institutions, especially women. This article focuses on another aspect of diversity, inequality and representation, the voices heard by parliamentary committees in their scrutiny of government actions and legislation.

The article discusses the current position in the Scottish Parliament (and other UK legislatures) with, for example, around three-fifths of witnesses at Holyrood being male, and highlights both 'demand' and 'supply' factors that influence the make-up of committee witnesses. It also identifies a number of functions that witnesses can play for committees, and how these relate to diversity and representation, and suggests that there may be benefits to committees and legislatures in hearing from a wider range of voices.

Keywords: Diversity, representation, gender, Scottish Parliament, participation.

\section{Introduction}

It has long been argued that some groups in society lose out significantly because they lack power, particularly those who are poor or otherwise socially excluded (for example, Miliband, 1974; Townsend, 1979; Williams, 1989; Oliver, 1990; Byrne, 1999; Lister, 2004). One aspect of this that has seen considerable attention in recent years has been the extent to which elected bodies are and should be representative of wider society, and this has also been linked to significant questions about their work, including their engagement with wider society, the quality of legislative scrutiny and oversight of government, and even the future of representative democracy.

This article suggests that many of these concerns can be considered in relation to the work done by parliamentary committees, and in particular the voices that they hear from when gathering evidence for their work. It draws upon a variety of literatures and empirical research in the Scottish Parliament to examine these issues. The focus here is primarily on gender, but many of the arguments and implications could be extended to other protected characteristics, and indeed to other attributes, such as geography or socio-economic status.

As noted above, one issue that has frequently been highlighted is the make-up of elected bodies, in particular with regard to the characteristics of representatives, and 
the extent to which they do or do not reflect the nature of their society, and what this means for democracy and the policy agenda. More recently this has been echoed in relation to the treatment of those working in such institutions, especially women. However, questions of equality, diversity and representation arguably extend beyond those inside representative bodies, whether elected or appointed, and can and should include the voices that legislatures hear from. In addition, there may be a variety of other reasons that legislatures, including through their committees, should be seeking to hear from a wider range of voices, not least in contributing to the scrutiny of government legislation and actions. The Inter-Parliamentary Union (IPU), for example, suggests that a gender-sensitive parliament 'responds to the needs and interests of both men and women in its structures, operations, methods and work' (Inter-Parliamentary Union, 2016: 6) and 'Mainstreams gender equality throughout all of its work' (Inter-Parliamentary Union, 2016: 7). However, while quite extensive, including communications and outreach policies and participation in public events held in parliaments, the IPU's selfassessment toolkit does not extend to the voices that a parliament's committees might hear from.

Committees are an important part of the parliamentary structure, and while their roles and powers vary across jurisdictions, they are often responsible for scrutinising government legislation and help hold governments, public bodies, and indeed others, accountable for their actions, including in relation to policy implementation (for example, through collecting evidence, questioning witnesses, producing reports and having access to the media). The committees of the Scottish Parliament are responsible for both legislative and executive oversight, and themselves have the power to introduce legislation, although that has rarely been used.

Drawing on a range of literatures, the article highlights the variety of potential benefits for parliaments that may be associated with hearing from a wide range of voices. In contrast, the analysis of witnesses who give evidence to committees of the Scottish Parliament shows that they are largely male and tend to be drawn from a relatively narrow range of organisations. It suggests that at a time of growing inequality and substantial political disengagement these considerations may be of even greater significance.

\section{Methodology}

There is relatively little information available on other parliaments, and the academic literature in this field, while growing, remains sparse. While using ideas from a variety of related fields, this article therefore draws significantly on new work. It involves semistructured interviews with sixteen MSPs (including ten current committee conveners), eight clerks, eight Scottish Parliament Information Centre (SPICe) researchers, and six other parliamentary staff, all of whom are involved in the identification of potential committee witnesses, between February and September 2017. The data from the interviews are analysed inductively with a focus on emerging themes, although this article seeks to reflect the wide range of perspectives on this topic. In addition, SPICe staff compiled a database of all committee witnesses in the parliamentary years 1999-2000, 2015-16 and 2016-17 using committee minutes. This included information on the organisation and gender of each witness, as well as the committee to which they gave evidence. Witnesses were classified by individual committee item. As committees do not currently record the 
gender identity of their witnesses, individuals were classified on the basis of their name, with the exception of one person who had requested prior to their appearance before a committee during the 2015-16 parliamentary year that they be noted as non-binary (they are excluded from the analyses unless specifically noted). The research received ethical approval through the University of Lincoln's standard processes.

\section{The Scottish Parliament, engagement and diversity}

For the Scottish Parliament, there have been a number of drivers of concerns about the diversity of voices heard by committees, including oral witnesses. Indeed, the Parliament was widely seen as having been created on the basis of founding principles of powersharing, accountability, openness, participation and equal opportunities (Commission on Parliamentary Reform, 2017), although in recent years both internal and external developments have contributed to maintaining a focus on these. While the Parliament might therefore be seen as having developed from a particular starting point, and to have a specific democratic transition, there are similar issues in other UK legislatures, as highlighted elsewhere in the article, and they also appear to be gaining traction internationally.

Within the Parliament, longstanding commitments to openness and participation have been reflected in documents such as the Committee Engagement Strategy, which also highlighted an increased focus on engagement and related priorities, including involving 'more people from a broader range of communities in the work of committees' (Scottish Parliament, 2015), the Public Engagement Strategy (Scottish Parliamentary Corporate Body, 2016), and the Diversity and Inclusion Strategy 2017-21 (Scottish Parliamentary Corporate Body, 2017), with the latter emphasising the desire for an open and accessible Parliament 'as a place to work, to visit and to participate' (Scottish Parliamentary Corporate Body, 2017: 2), the importance of public engagement activities, and the need to ensure that the Parliament has 'the knowledge and expertise to make better informed decisions about the needs and experiences of all diverse groups' (Scottish Parliamentary Corporate Body, 2017: 6). As happened in the UK Parliament, allegations of sexual harassment emerged during 2017 and led to a number of initiatives aimed at preventing such behaviour in the institution (Standards, Procedures and Public Appointments Committee, 2018). Finally, the report of the Commission for Parliamentary Reform, established by the new Presiding Officer in 2016 to reflect on the first eighteen years of the Parliament's existence and to consider how it could enhance scrutiny and better engage with the people of Scotland, placed considerable emphasis on the effectiveness of committees and on diversity, including suggesting that 'efforts must be made to ensure all voices are heard' (Commission on Parliamentary Reform, 2017: 14).

Outside the Parliament, in addition to more general debates about political engagement, equality and diversity in contemporary society, the Scottish Government's proposals and enactment of legislation for an objective of equal gender representation on the boards of public bodies arguably gave added impetus to discussions on gender and highlighted women's under-representation in many aspects of civil, political and social life. During the period of the research, the \#MeToo campaign also reflected some of the concerns about the treatment of women, including within the Westminster and Holyrood Parliaments, and reinforced wider concerns about inequalities. 


\section{Why does diversity of committee witnesses matter?}

As noted above, in many legislatures, committees are of significant importance in the scrutiny of government legislation and policies, not least through gathering formal written and oral evidence (and sometimes informal evidence), producing often authoritative reports and placing information in the public domain, and there is some evidence that these can have a real impact on governments (for example, Benton and Russell, 2013; White, 2015; Russell and Gover, 2017). In Scotland, in addition, it has been argued that, in line with wider attempts to make the new Parliament more open, inclusive and transparent (Mitchell, 2000; Megaughin and Jeffery, 2009), committees were designed to enhance the role of civil society in the legislative process (Consultative Steering Group, 1998; Bonney, 2003), and to engage the public proactively, including traditionally excluded groups. The Scottish case therefore is a valuable one, although, as with other parliaments, it has been suggested that the 'usual suspects' remain the dominant players giving evidence to committees (Cairney et al., 2009; Halpin et al., 2012; Pedersen et al., 2015).

Committees can also be seen as an important linkage between the state and civil society (Hough, 2012), allowing the public to engage directly with their elected representatives (Reader, 2015), transmitting information about what voices parliaments hear from and value, and potentially acting as a form of representation between elections (Pedersen et al., 2015). Oral witnesses, in particular, are visible to commentators and the public in a way that those who submit written evidence are not, while they are also subject to a form of selection, as discussed in greater depth below, which does not apply to those who provide written evidence, and indeed some witnesses will not have submitted written evidence prior to their appearance before a committee.

It is possible to draw on a variety of literatures to argue that there are likely to be benefits to legislatures from committees hearing from a wider range of voices. While there is clearly some overlap (see also Childs, 2016, for an in-depth consideration of 'the good parliament' in relation to gender at Westminster), these can be seen as fitting within three broad themes: representation, policy-making and evaluation, and participation and legitimacy.

\section{Representation}

Notions of representation are clearly important to parliaments, with Pitkin's (1967) framework (including replicating the characteristics of society, acting on behalf of individuals or groups, acting as a symbol by standing for something, such as women or ethnic minorities, or a representative being free to make decisions as they please once they have been elected), having been particularly influential, although also subject to some significant criticisms (for example, Childs and Lovenduski, 2013). Many of these ideas have been developed particularly with regard to women and elected representatives, including that women are often underrepresented, and that female representatives can and do provide substantive representation (Childs, 2004; Celis and Childs, 2008), may be more likely to raise policy issues such as domestic violence (Goetz, 1998) and women's access to the labour market (Celis, 2006), and to support policies that might increase equality (Kittilson, 2011). Some have also sought to extend feminist arguments about the representation of women to participation in non-electoral elements of democratic processes (for example, Agustín, 2008; Rumbul, 2016) and public workforces (Johnston 
Miller, 2012), and suggested that institutional structures are key to facilitating the representation of marginalised groups (for example, Weldon, 2002), with parliamentary committees providing an obvious and important example of elements of the democratic process that citizens and groups can engage with, so that it can be argued that 'presence' (Phillips, 1995) is therefore important in these areas. More recently, Saward $(2010,2016)$ and others for example, (Severs, 2010, 2012) have taken arguments about representation in a somewhat different direction, suggesting that some groups in society, including perhaps those who are not descriptively represented, or whose views may not normally reach policy makers, such as children or poorer people (for example, Lister, 1990; Tisdall, 2014; Garthwaite, 2016), may benefit from claims of representation made by those who are not themselves elected. Such debates are of growing importance, given that increasing economic and social inequality, combined with changes in the fabric of the representative system, can be seen as having further increased the power of the rich in many democracies, enabling them to 'entrench their own economic advantage and insulate their wealth in ways not open to poorer citizens' (Parvin, 2018: 271).

\section{Policy-making and evaluation}

From a rather different starting point, drawing on literature on the making, oversight and evaluation of policy, there are arguments that a greater range of voices can provide different perspectives (Liaison Committee, 2015; Engender, 2016), including from those who are responsible for implementing and who are affected by policy and legislation (Cabinet Office, 2012), and that, in turn, may inform scrutiny by informing committees (Thompson, 2014; Hendriks and Kay, 2017) and helping committee members develop expertise (Geddes, 2018). Similarly, it has been suggested that input from a wider variety of voices and interests can provide additional external challenges to policy and legislation (Cabinet Office, 2012), leading to better (Modernisation Committee, 2006; Liaison Committee, 2012) and more transparent scrutiny (Marsh and Miller, 2012), and, in turn, can potentially lead to improved outcomes (Social Exclusion Unit, 2000; Ilot and Norris, 2015), more effective policy implementation (OECD, 2017) and evaluation (Plottu and Plottu, 2009), and increased legitimacy (Albertyn, 2003; White, 2009), including by providing greater awareness of society's views and increasing the ability of policy makers to respond to public concerns; while Hendriks and Kay (2017) emphasise the possibilities for enhancing the 'deliberative capacity' of committees. The OECD have highlighted, in a review of gender equality in Canada, the importance of parliaments and parliamentary committees in this regard, and the benefits of a broader range of witnesses:

Ensuring a degree of diversity among experts who give evidence to committees, in terms of gender, but also ethnicity, sexuality, disability, etc., helps to ensure that policy making is fully informed by the range of experiences facing Canadians, and that persistent policy gaps are highlighted and exposed to challenge (OECD, 2018: 95).

\section{Engagement, participation and legitimacy}

There are a range of other arguments associated with democracy and the participation and engagement of the public, and the potential for enhanced legitimacy for institutions, that further support the idea of committees hearing from a range of witnesses. Some of these are related to the considerable evidence that levels of political trust among the 
public have fallen over time, and the attempts that have been made by governments and others seeking to improve the ways in which citizens engage with and view the political system (Brodie et al., 2011; King, 2009; Seyd et al., 2018), the importance of social capital and the role of civil society (Whiteley, 2012). Hendriks and Lees-Marshment (2018) have recently explored how political decision-makers view public input, and suggest that they frequently value public input, but that their preferences tend not to be for formal consultation processes, rather being for more informal dialogic systems, and committees are a potential area for providing greater connections between citizens and politicians.

Other arguments are more specific to the operation of committees themselves, so that, for example, Halpin et al. (2012) note that although it is clearly important for committees to hear from those with expertise, hearing from only a limited range of voices might be conceived as being counter-democratic, while Geddes (2018) argues that committees can give citizens a voice, allowing them to voice concerns over policies.

While the bulk of the ideas outlined above relate to the 'inward facing' elements of the work of parliaments and governments, there are also 'outward facing' pressures, reflecting a recognition that the activities of parliaments will be seen and interpreted by those outside, including the media, civil society organisations and the public, and that the selection of witnesses therefore also matters because it sends a message to those outside parliaments about how the institutions work, what they are interested in and who they listen to. This also reflects suggestions that trust and legitimacy can be enhanced (Hardin, 2013; Leston-Bandeira, 2014) by the public feeling better represented by a parliament that looks more like them and which is more responsive to them (Childs and Lovenduski, 2013). Indeed, albeit from a somewhat different perspective, the Commission on Parliamentary Reform (2017) found that people often valued their involvement with committees, and that for many the experience encouraged them to learn more about and become involved in the work of the Parliament, as also reported by Bochel (2013) with regard to the petitions committee in the National Assembly for Wales. Indeed, Dean's (2018) work on participation in social policy in the United Kingdom usefully highlights the potential two-way links between policy-making and legitimacy by emphasising that a willingness to participate increases with more positive perceptions of institutions.

\section{Committees and witness diversity}

Given the arguments outlined above, and despite many of these potential benefits being difficult to assess (for example, Loeffler and Martin, 2016), it is perhaps unsurprising that recent years have seen a greater emphasis on the quality of evidence gathered by and the variety of voices that are heard by committees in a number of legislatures, particularly in the United Kingdom.

However, even where there are deliberate attempts to open up processes, as with petitions systems, publication of draft bills and more open calls for evidence, significant challenges remain, including in relation to existing disparities of power and resources (for example, Barnes et al., 2007), fairness of process and the management of expectations (Bochel, 2016), as well as the potential difficulties associated with balancing attempts to develop more participative forms of democracy alongside traditional representative democracy (for example, Bandeira and Ferraro, 2017; Bochel and Bochel, 2017). It is therefore not surprising that there have been concerns expressed that parliamentary committees continue to a large extent to listen to the 'usual suspects' (for example, 
Halpin et al., 2012; Liaison Committee, 2012; Pedersen et al., 2015), who also arguably have better access than other interests through other parts of the political and policymaking processes (McGarvey and Cairney, 2008). This section outlines the relatively limited material that considers who committees hear from, before the article moves on to consider the position in the Scottish Parliament.

\section{The United Kingdom Parliament}

Although there have been relatively few studies of the characteristics of witnesses to parliamentary committees, in the United Kingdom, in particular, that has begun to change in recent years. The Westminster Parliament, and the House of Commons in particular, has seen a considerable increase in emphasis on issues of equality and diversity in recent years, including in relation to elected members and staff, and with regard to gender (for example, The Good Parliament report: Childs, 2016) and select committee witnesses, with the Commons publishing statistics for the gender of committee witnesses in its Sessional Return since 2013 (for example, House of Commons, 2017). As with the Scottish Parliament, at least some of the pressures for more information, and indeed for change, have come from inside the institution. While there are some differences between the two chambers - not least the fact that in the Commons public bill committees (for which there are no figures on the make-up of witnesses), rather than select committees, scrutinise legislation - Westminster nevertheless provides a useful comparator.

The work of Berry and Kippin (2014) was important in highlighting the make-up of select committee witnesses and encouraging interest in the topic, showing that, in one month in 2013, of 583 witnesses only 144 (25 per cent) were women, and that there were significant differences across committees. They also found that 41 per cent of witnesses came from the public sector (with, perhaps unsurprisingly, ministers and officials from central government departments dominating), 20 per cent from the notfor-profit sector, and 18 per cent from the private sector; similarly, trade associations were prominent; and academic witnesses were disproportionately drawn from London. Although recognising that committees do not have a completely free hand in identifying and selecting witnesses, so that ministers, senior civil servants, and the heads of public bodies and other organisations are very likely to be chosen, they argued that, given the gender disparities among witnesses that committees do have more control over, 'committees are contributing to this problem as well as being subject to its effects' (Berry and Kippin, 2014: 15). Geddes (2018) also noted a considerable reliance for witnesses on charities, campaign groups, business and trade associations and professional associations, and showed that witnesses from the private sector were most likely to be male, followed by those from government and the civil service, while those from not-for-profit bodies were most likely to be female, with politicians, the public sector and higher education coming between the two extremes. He also argues that concerns to achieve a politically balanced set of witnesses mean that representation of political ideas has generally trumped concerns over social diversity.

Within the House of Commons, the Liaison Committee (2015) suggested that, while select committees have made considerable efforts at promoting engagement, the level of activity aimed at reaching those sections of society that are disenchanted with and disengaged from mainstream processes 'seems out of kilter with the scale of the challenge' (Liaison Committee, 2015: 47). Indeed, in 2018 the Committee agreed that unless panels 
involve specific office holders, those with three or more witnesses should normally include at least one woman, that statistics should be published regularly, and that by the end of the Parliament the aim should be for at least 40 per cent of 'discretionary' witnesses to be female (Liaison Committee, 2018).

\section{Other legislatures}

While most information is available about Westminster, in many respects the Nordic states (Denmark, Finland, Iceland, Norway and Sweden) would appear to be appropriate comparators for the Scottish Parliament, having unicameral parliaments, strong party discipline, and committees that combine scrutiny of legislation with that of the executive, while they also frequently have minority or multi-party governments. The other devolved legislatures in the United Kingdom, the Northern Ireland Assembly and the National Assembly for Wales, are also obvious comparators. However, none of these bodies collects data on committee witnesses, making academic studies the sole source of information.

In one of the few pieces of comparative work, Pedersen et al. (2015) examined the national parliaments of Denmark, the Netherlands and the United Kingdom, which they argue reflect important similarities and differences in institutional design. They show that parliamentarians consider issues of both representation and information quality when seeking actors to give evidence, with 'representation' being largely about engagement with external stakeholders relevant to the topic being considered, and information quality reflecting a desire to be as fully informed as possible about the issue, with a consequent preference for engagement with those who are knowledgeable about the issue and who can contribute new perspectives. Their research suggests that where there is open access interest groups tend to be more dominant and the provision of evidence tends to be concentrated in the hands of fewer actors; closed access procedures mobilise different types of actors (such as experts and private companies), while the evidence comes from a broader number of actors.

Like the Scottish Parliament, the National Assembly for Wales has had high levels of women's representation among its members, and values such as 'equality' and 'diversity' prominent in its founding principles. However, Rumbul (2016) has shown that despite the focus on the substantive and descriptive representation of women in elected office, across the first twelve years of the Assembly's existence only 27 per cent of committee witnesses were female, with only a very slight upward trend over time. She found that committees concerned with areas such as agriculture and transport heard from largely male witnesses, with only those looking at education and health and social care having more than forty per cent female witnesses. Similarly, Maxwell (2017), having examined five committees in each of the Northern Ireland Assembly, National Assembly for Wales and Scottish Parliament, found that in each legislature male witnesses typically outnumbered female witnesses by around two to one, with subjects such as agriculture and business having the smallest proportion of women, and education and health the smallest gaps in representation.

\section{Witnesses and diversity in the Scottish Parliament}

For the Scottish Parliament, as with other legislatures, there are clearly a variety of pressures and initiatives affecting witness selection, and indeed evidence gathering more 
Table 1 Gender of committee witnesses, 1999-2000, 2015-16, 2016-17 (percentages)

\begin{tabular}{llllll}
\hline \hline \multicolumn{2}{c}{ 1999-2000 } & \multicolumn{2}{c}{ 2015-16 } & \multicolumn{2}{c}{ 2016-17 } \\
\hline Female & Male & Female & Male & Female & Male \\
25.1 & 74.9 & 35.9 & 64.0 & 38.2 & 61.8 \\
\hline \hline
\end{tabular}

generally, as outlined above. The work of Halpin et al. (2012) provided valuable insights into the work of the Parliament's committees during the 1999-2003 and 2003-7 sessions. They found that different tiers of government were the largest single category of actor, while individuals and citizen groups were the second and third most common types of actor, and suggested that an invitation to give oral evidence was a proxy for privileged access, with few individuals being invited to give oral evidence. Importantly, in relation to marginalised groups, they examined hearings likely to have a discernible impact on the black and minority ethnic population, disabled people and children, and found that around a quarter (23 per cent) of all committee issues were likely to affect children, and around 8 per cent disabled people, while even in these sectors the most active contributors were generalist organisations, and particularly those from the public sector.

The discussion below draws upon interviews with MSPs and parliamentary staff, and the database of committee witnesses developed for this research, to consider further what is known about who gives oral evidence and the views of respondents on this. While the focus is on those who provide oral evidence, it is important to recognise that committees receive 'evidence' in a number of forms and through a variety of different paths. Typically, written evidence is sought prior to committees hearing oral evidence, and can inform both the selection of witnesses and the line of inquiries of committees. However, committees also utilise a variety of other forms of information gathering, including less formal activities such as visits, informal breakfast meetings and using social media, while MSPs also receive input through contacts with constituents, organised interests and others.

Table 1 shows the proportion of witnesses by gender for formal evidence sessions in the Scottish Parliament for the three years for which data was collated. Alongside a marked increase in the numbers of committee witnesses (from 848 in 1999-2000 to 1,931 in 2015-16 and 1,897 in 2016-17), there has been a significant increase in the proportion of witnesses who are women. Indeed, the figures for Scotland clearly reflect a higher proportion of female witnesses than in the National Assembly for Wales or at Westminster.

As with other legislatures, there are also very significant differences across committees in terms of both the number and gender of witnesses, with some hearing relatively little oral evidence, while others hear from many witnesses, as illustrated by Figure 1. Although the proportions vary somewhat each year, broadly speaking, subject areas such as health and social care and education tend to see more female witnesses, while others, such as finance, rural and farming issues, and local government tend to hear more from men. In 2016-17, the Equalities and Human Rights Committee had 64 per cent female witnesses, and the Health and Sport Committee 54 per cent, while for the Rural Economy and Connectivity Committee and the Finance and Constitution Committee the figures were 18 and 14 per cent respectively. 


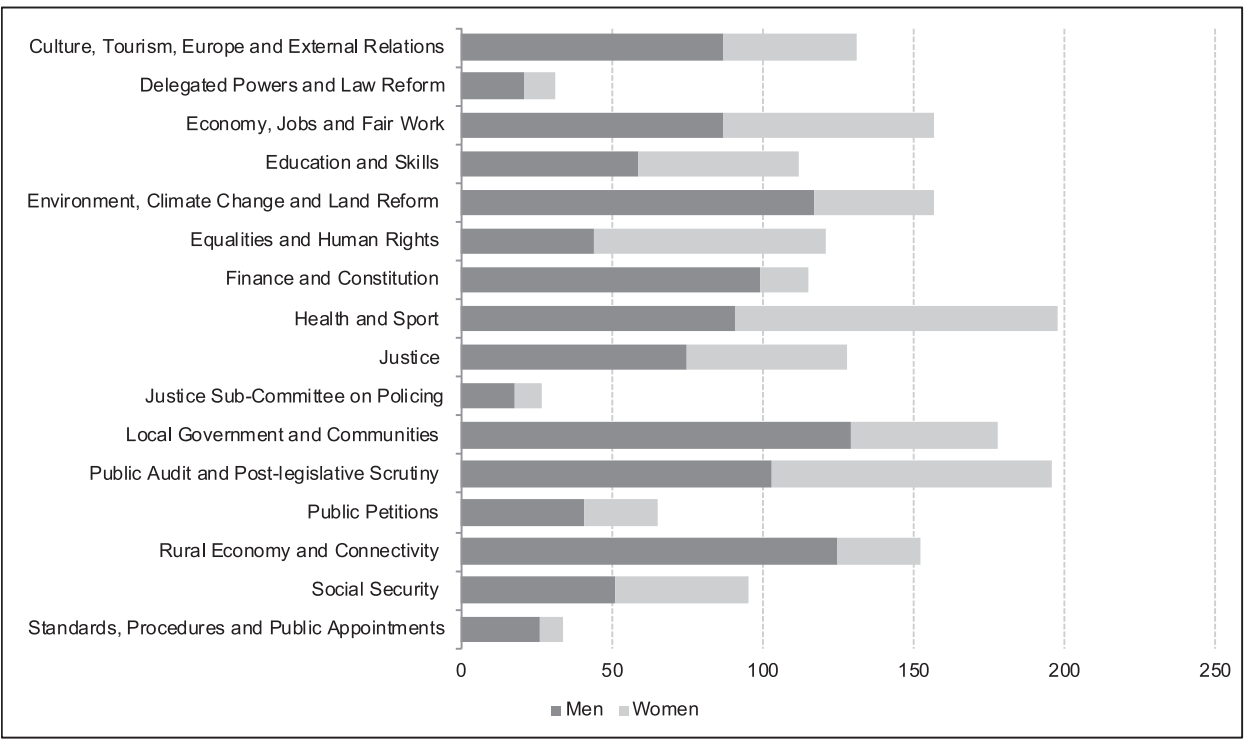

Figure 1. Number and gender of committee witnesses, 2016-17.

Of course, the Parliament's committees do not always have control of who witnesses are, and there are, inevitably, both 'demand' and 'supply' dimensions. 'Supply' is perhaps most significant where the concerns are over issues such as accountability, when it is likely to be necessary or desirable to have particular individuals appear before committees, or legislation, when evidence will be required from both ministers and civil servants, and is perhaps most obvious for the Scottish Government, which is the largest single provider of witnesses, whether ministers or officials. Since 2014, the Scottish Cabinet has been composed of equal numbers of men and women, but during 2016-17, of the 163 ministerial witnesses, 101 (62 per cent) were male, while of the 280 officials who appeared as witnesses, 190 (68 per cent) were male. For ministers, the differentials may, perhaps, be at least partially explained by the fact that the First Minister, Nicola Sturgeon, rarely appears before committees.

Table 2 shows organisations other than the Scottish Government that provided ten or more witnesses during 2016/17 (excluding universities, where some witnesses were selected as representing institutions while others were appearing as experts in particular fields, and the Scottish Parliament itself, where similar caveats apply). These figures again reflect some impact of 'supply' related to the nature of the subject matter and the gender balance of potential witnesses (for example, most of the more senior figures in Police Scotland were male, while thirty-two of the appearances for Audit Scotland were by the (female) Auditor General).

Higher education institutions, within and beyond Scotland, are also a significant source of witnesses, although in most cases they will be giving evidence on the basis of individual expertise, rather than on behalf of an institution. Of the 111 academic witnesses during 2016-17, 62 per cent were male - Higher Education Statistics Agency (HESA) figures suggest that 59 per cent of academic staff were male in 2016/17. And of 
Table 2 Number of witnesses by organisation and gender, 2016-17

\begin{tabular}{lcc}
\hline \hline & Female & Male \\
\hline Audit Scotland & 69 & 50 \\
Transport Scotland & 5 & 30 \\
Police Scotland & 3 & 19 \\
Convention of Scottish Local Authorities & 12 & 7 \\
Education Scotland & 3 & 9 \\
NHS Tayside & 5 & 7 \\
Scottish Funding Council & 2 & 8 \\
Scottish Police Authority & 0 & 10 \\
\hline \hline
\end{tabular}

the seventy academic witnesses who were professors, 66 per cent were male - HESA figures suggest that 76 per cent of professors across the UK were male in 2016/17.

Taking a wider overview, non-profit organisations and NHS bodies tended to provide significant proportions of female witnesses, while trade unions, local authorities, private companies and police bodies tended to send more men. In addition, the Parliament's committees make considerable use of witnesses from 'representative bodies' or umbrella organisations, and this was widely seen as valuable in allowing engagement with key stakeholders and accessing specialist knowledge and experience, although at the same time many recognised that '... there can be issues about how representative they are, who of, etc.' - official 13. This would appear to align them, in some respects at least, more with the practices of committees in the Nordic states, which make greater use of such bodies, than with Westminster (Arter, 2003; McAllister and Stirbu, 2007).

From a 'demand' perspective, it was clear from the interviews that while there was considerable desire for a more diverse set of witnesses (' ... we should not default to policy and PR people' - MSP 4; 'Quite often we get sent high up officials, including chief executives, who need briefing before they appear; my view is that we should get the person who knows about the subject in the first place. I was also aware that we need to tackle the gender balance' - MSP 8), there were also challenges associated with any such moves, both in terms of what is sought by committees ('I look for witnesses who are informed and who will be able to add to the sum of our knowledge - I care not if they are male or female, I have no preference, but want the best person, the most knowledgeable person, to give the best possible advice' - MSP 5) and the practicalities ('We do not try and control who organisations send' - official 5). However, there was considerable support for the idea of the Parliament encouraging organisations to consider diversity, and for the provision of training and support for potential witnesses.

There was a broad pattern of witnesses holding senior positions in their organisations, and while in many respects that may be both understandable and desirable from committees' perspectives, particularly where there are questions of accountability, but also sometimes for other reasons ('Appearing before a committee can be challenging you need to be resilient, be able to accept responsibility, and if you have less senior people it may be necessary for them to go back to consult on a question, which may not be ideal. More senior people may feel more able to respond on something where an organisation's line is less clear' - official 12), it does highlight that there is a potential risk of hearing 
primarily from those in managerial and strategic positions, rather than those involved in 'frontline' service provision, or those who are directly affected by policy, such as service users ('I think that we need a mix of witnesses - experts can be helpful, but we can be a bit expert-heavy, and we do not always hear from the people that policies impact on; we need to hear from the people who use services as their evidence can be both insightful and persuasive - they know what really happens' - MSP 16; 'we tend to get the corporate views, when sometimes it might be more useful to get the frontline view' - official 11).

The role and functions of witnesses. As noted briefly above, interviewees, perhaps unsurprisingly, emphasised that the primary purpose of hearing oral evidence was to contribute to good scrutiny and to holding the government to account, for which 'it is very important to have a high-quality evidence base' (official 6), although there was only limited agreement about what might constitute that. Views tended to coalesce around four main concerns, each of which might be seen as having particular implications for the type of witnesses:

- Accountability, whether of the Scottish Government or other organisations, with the primary concern being to hear from those in responsible positions, so that committees may have little or no choice over who appears before them;

- In a representative capacity, in particular key stakeholders and umbrella bodies which may have some form of representative mandate. This can help bring special knowledge to committee inquiries, while also having efficiency benefits, reducing the need to collate information from a range of voices (Geddes, 2018), and here the Parliament's ability to influence who appears may be somewhat limited, although a number of respondents did suggest that such organisations could be encouraged to send more diverse witnesses;

- To provide expertise, often drawn from individuals, and in these instances the number of potential witnesses may be larger or smaller depending on the topic, although some interviewees argued that the Parliament could do more to develop greater diversity among this type of witness;

- To talk about their experiences, whether on the delivery or the receiving side of legislation and policy, and here many respondents suggested that there may be greater opportunities to identify more diverse groups of witnesses.

All of these clearly relate to the policy-making and evaluation process, and while the idea of a representative capacity is clearly present in the second, it was not associated with an application to Scottish society, and only the fourth shows a clear and consistent link to concerns over diversity.

However, two further significant strands of thought could be identified, which not only emphasise the inward and outward looking benefits for more diverse witnesses, but also relate clearly to ideas that are seen in the literatures on representation, policy-making and participation discussed earlier:

- The benefits to Parliament from having witnesses who could provide a diverse range of views, often relating to the types of arguments outlined earlier in this article, such as providing additional insights, detailing their experiences, and potentially raising different issues and concerns; 
- The selection of witnesses is important because of the messages that it can send to people outside Parliament about how Parliament works, what it is interested in and who it listens to.

A number of interviewees also took broader views both about diversity itself, with many suggesting that gender was a useful starting point ('It is important that we do not just consider gender diversity - there is disability, socio-economic difference, geography, etc.' - MSP 13; '... we very infrequently have people under $35^{\prime}$ - official 6), and the subject matter, perhaps reflecting the tendency for women to be more likely to appear before particular committees ('... we do not want women giving evidence only on "women's issues" - official 1'). There was also a recognition that efforts to engage with a wider range of groups and to hear different voices would be likely to require different approaches and additional resources. However, even among those who were most supportive of greater diversity among witnesses, there was little support for quotatype mechanisms, and an awareness that 'simply replacing men with very similar women' (official 11) would not reflect other social or economic inequalities.

Finally, it is worth reiterating that the Scottish Parliament's committees do undertake a considerable variety of evidence-gathering beyond that which is formally recorded as oral or written evidence, with examples ranging from the use of social media to gather views on particular issues, through site visits (for example, to hear from destitute asylum seekers, or the views of school pupils on human rights) to private meetings (as with survivors of domestic abuse). These activities were seen by interviewees as beneficial, in particular for providing different views and insights from those likely to be heard in formal evidence sessions, and as consequently providing different drivers for inquiries and allowing the exploration of more issues with regard to the delivery of services.

\section{Conclusions}

There has been growing interest in ways of enhancing representative democracy and in hearing the voices of more elements of society, in part as a response to a perceived decline in political engagement and growing economic, social and power inequalities. However, while committees play an important role in many legislatures, including the Scottish Parliament and Westminster, relatively little is known about the voices that they hear from, nor about the role that they could play in such processes. Yet there appear to be a variety of good reasons for Parliaments to hear from, and be seen to be listening to, a diverse range of voices, including in relation to representation of wider society, contributions to the quality of policy and evaluation, and enhancing engagement and legitimacy, particularly in relation to groups who may be less able to access political and governmental structures. The evidence from Holyrood shows that, with regard to those who give oral evidence, while significant progress may have been made over time, in particular with an increase in the proportion of female witnesses, those who appear before committees are still likely to be male, to be drawn from a relatively limited set of organisations and perhaps interests, and to hold more senior positions. In addition, the interviews suggest that while there was a considerable degree of consensus in the views of MSPs and officials involved in the selection of witnesses about the contributions that oral evidence can make, they nevertheless differ somewhat in relation to who they wish to hear from, with some emphasising the quality of information and 'expertise', and 
others the benefits of hearing from a wider range of voices, including those who provide and use public services. Of course, these positions are not necessarily incompatible, but can be seen as reflecting different paths that committees can take in seeking to undertake informed, high quality scrutiny. In addition, some highlighted notions of representation and fairness that they felt should be taken into account in the identification of witnesses, and also the importance of the Parliament being aware of the message that witness selection can send to wider society.

In line with its founding principles, and also reflecting more recent developments and pressures, the Parliament is clearly seeking to hear from different parts of Scottish society, including those which are less likely to be in contact with the institutions of government and Parliament, and has a number of strategies in place that are intended to address many of the issues, including having established a Committee Engagement Unit in 2018 to encourage the participation of a greater number and wider range of people (see also Hendriks and Kay (2017) for suggestions on committees and public engagement), although with regard to witnesses the varied needs of committees are likely to remain a challenge. There are, of course, other issues associated with any attempt by parliaments to hear a broader range of voices, as with wider participatory initiatives, such as how 'representation' is assessed, how different categories of publics are produced and targeted, and how difference is accommodated (see, for example, Barnes et al., 2007). In addition, given the growth in the variety of more participative means of public engagement, there will almost inevitably be tensions between participative and representative elements, as well as challenges in considering the implications of additional voices and ideas for policy and legislation. However, enabling wider input through the committee system may at least help link more participative inputs with a key element of the representative parliamentary process, strengthening representative democracy and strengthening scrutiny and oversight.

\section{References}

Agustín, L. (2008) 'Civil society participation in EU Gender policy-making: framing strategies and institutional constraints', Parliamentary Affairs, 61, 3, 505-17.

Albertyn, C. (2003) 'Towards substantive representation: women and politics in South Africa', in A. Dobrowolsky and A. Hart (eds), Women Making Constitutions, Basingstoke: Palgrave Macmillan, 99-117.

Arter, D. (2003) The Scottish Parliament: A Scandinavian-Style Assembly?, London: Frank Cass.

Bandeira, P. and Ferraro, A. (2017) 'Integrating participatory institutions into the traditional representative and bureaucratic model of public governance', International Political Science Review, 38, 5, 64258.

Barnes, M., Newman, J. and Sullivan, H. (2007) Power, Participation and Political Renewal: Case Studies in Public Participation, Bristol: Policy Press.

Benton, M. and Russell, M. (2013) 'Assessing the impact of parliamentary oversight committees: the select committees in the British House of Commons', Parliamentary Affairs, 66, 4, 772-97.

Berry, R. and Kippin, S. (2014) Parliamentary Select Committees: Who Gives Evidence?, London: Democratic Audit.

Bochel, C. (2013) 'Petitions systems: contributing to representative democracy?', Parliamentary Affairs, 66, $4,798-815$.

Bochel, C. (2016) 'Process matters: petitions systems in Britain's legislatures', Journal of Legislative Studies, $22,3,368-84$. 
Bochel, C. and Bochel, H. (2017) "Reaching in"? The potential for e-petitions in local government in the United Kingdom', Information, Communication and Society, 20, 5, 683-99.

Bonney, N. (2003) 'The Scottish Parliament and participatory democracy: vision and reality', Political Quarterly, 74, 4, 459-67.

Brodie, E., Hughes, T., Jochum, V., Miller, S., Ockenden, N. and Warburton, D. (2011) Pathways Through Participation: What Creates and Sustains Active Citizenship?, London: Participation Compass.

Byrne, D. (1999) Social Exclusion, Buckingham: Open University Press.

Cabinet Office (2012) The Civil Service Reform Plan, London: Cabinet Office.

Cairney, P., Halpin, D. and Jordan, G. (2009) 'New Scottish Parliament, same old interest group politics?' in C. Jeffery and J. Mitchell (eds.), The Scottish Parliament 1999-2009: The First Decade, Edinburgh: Luath Press, 105-12.

Celis, K. (2006) 'Substantive representation of women: the representation of women's interests and the impact of descriptive representation in the Belgian Parliament (1900-1979)', Journal of Women, Politics and Policy, 28, 2, 85-114.

Celis, K. and Childs, S. (2008) 'The descriptive and substantive representation of women: new directions', Parliamentary Affairs, 61, 3, 419-25.

Childs, S. (2004) New Labour's Women MPs: Women Representing Women, London: Routledge.

Childs, S. (2016) The Good Parliament, Bristol: University of Bristol.

Childs, S. and Lovenduski, J. (2013) 'Political representation', in G. Waylen, K. Celis, J. Kantola and L. Weldon (eds.), The Oxford Handbook of Gender and Politics, Oxford: Oxford University Press, 489-513.

Commission on Parliamentary Reform (2017) Your Parliament, Your Voice: Report on the Scottish Parliament, Edinburgh: Commission on Parliamentary Reform.

Consultative Steering Group (1998) Shaping Scotland's Parliament, Edinburgh: Scottish Office.

Dean, R. (2018) 'Control or influence? Conflict or solidarity? Understanding diversity in preferences for public participation in social policy decisions making', Social Policy and Administration, https://doi.org/10.1111/spol.12445.

Engender (2016) Equal Voice, Equal Power: The Case for Gender Quotas in Scotland, Edinburgh: Engender. Garthwaite, K. (2016) Hunger Pains: Life Within Foodbank Britain, Bristol: Policy Press.

Geddes, M. (2018) 'Committee hearings of the UK Parliament: who gives evidence and does this matter?', Parliamentary Affairs, 71, 2, 283-304.

Goetz, A. (1998) 'Women in politics and gender equality in policy: South Africa and Uganda', Review of African Political Economy, 25, 76, 241-62.

Halpin, D., MacLeod, I. and McLaverty, P. (2012) 'Committee hearings of the Scottish Parliament: evidence giving and policy learning', Journal of Legislative Studies, 18, 1, 1-20.

Hardin, R. (2013) 'Government without trust', Journal of Trust Research, 3, 1, 32-52.

Hendriks, C. and Kay, A. (2017) 'From "opening up" to democratic renewal: deepening public engagement in legislative committees', Government and Opposition, https://doi.org/10.1017/gov.2017.20.

Hendriks, C. and Lees-Marshment, J. (2018) 'Political leaders and public engagement: the hidden world of informal elite-citizen interaction', Political Studies, https://doi.org/10.1177/0032321718791370.

Hough, R. (2012) 'Do legislative petitions systems enhance the relationship between parliament and citizen?', Journal of Legislative Studies, 18, 3, 479-95.

House of Commons (2017) Sessional Returns: Session 2016-17, London: House of Commons.

Ilot, O. and Norris, E. (2015) Smarter Engagement: Harnessing Public Voice in Policy Challenges, London: Institute for Government.

Inter-Parliamentary Union (2016) Evaluating the Gender Sensitivity of Parliaments: A Self-Assessment Toolkit, Geneva: Inter-Parliamentary Union.

Johnston Miller, K. (2012) 'Representative bureaucracy and multi-level governance in the EU', Geopolitics, History and International Relations, 4, 1, 50-75.

King, A. (2009) The British Constitution, Oxford: Oxford University Press. 
Kittilson, M. (2011) 'Women parties and platforms in post-industrial democracies', Party Politics, 17, 1, 66-92.

Leston-Bandeira, C. (2014) 'The pursuit of legitimacy as a key driver for public engagement: the European Parliament case', Parliamentary Affairs, 67, 2, 415-36.

Liaison Committee (2012) Select Committee Effectiveness, Resources and Powers, London: The Stationery Office.

Liaison Committee (2015) Building Public Engagement: Options for Developing Select Committee Outreach, London: The Stationery Office.

Liaison Committee (2018) Witness Gender Diversity, London: The Stationery Office.

Lister, R. (1990) The Exclusive Society, London: Child Poverty Action Group.

Lister, R. (2004) Poverty, Cambridge: Polity.

Loeffler, E. and Martin, S. (2016) 'Citizen engagement', in T. Bovaird and E. Loeffler (eds.), Public Management and Governance, London: Routledge.

McAllister, L. and Stirbu, D. (2007) 'Developing Devolution's potential: a comparative evaluation of the National Assembly for Wales's subject committees', Policy and Politics, 35, 2, 289-309.

McGarvey, N. and Cairney, P. (2008) Scottish Politics: An Introduction, Basingstoke: Palgrave Macmillan.

Marsh, I. and Miller, R. (2012) Democratic Decline and Democratic Renewal: Political Change in Britain, Australia and New Zealand, Cambridge: Cambridge University Press.

Maxwell, A. (2017) Who Appears Before Statutory Committees in the Northern Ireland Assembly: A Comparative Analysis of Witness Diversity, an unpublished dissertation submitted in partial fulfilment of the degree of Masters of Arts in Legislative Studies and Practice, Belfast: Queen's University.

Megaughin, E. and Jeffery, C. (2009) 'Introduction: the first decade', in C. Jeffery and J. Mitchell (eds.), The Scottish Parliament 1999-2009: The First Decade, Edinburgh: Luath Press, 9-14.

Miliband, R. (1974) 'The politics of poverty', in D. Wedderburn (ed.), Poverty, Inequality and Class Structure, Cambridge: Cambridge University Press, 183-96.

Mitchell, J. (2000) 'New parliament, new politics in Scotland', Parliamentary Affairs, 55, 3, 605-21.

Modernisation Committee (2006) The Legislative Process, London: The Stationery Office.

OECD (2017) The Pursuit of Gender Equality: An Uphill Battle, Paris: OECD.

OECD (2018) Gender Equality in Canada: Mainstreaming, Governance and Budgeting, Paris: OECD.

Oliver, M. (1990) The Politics of Disablement, Basingstoke: Palgrave Macmillan.

Parvin, P. (2018) 'Representing the people: British democracy in an age of political ignorance', Political Studies Review, 16, 4, 265-78.

Pedersen, H., Halpin, D. and Rasmussen, A. (2015) 'Who gives evidence to parliamentary committees? A comparative investigation of parliamentary committees and their constituencies', Journal of Legislative Studies, 21, 3, 408-27.

Phillips, A. (1995) The Politics of Presence, Oxford: Oxford University Press.

Pitkin, H. (1967) The Concept of Representation, Berkeley: University of California Press.

Plottu, B. and Plottu, E. (2009) 'Approaches to participation in evaluation: some conditions for implementation', Evaluation, 15, 3, 343-59.

Reader, N. (2015) 'Assessing the policy impact of Australia's parliamentary electoral matters committees: a case study of the Victorian Electoral Matters Committee and the introduction of direct electoral enrolment', Parliamentary Affairs, 68, 3, 494-513.

Rumbul, R. (2016) 'Gender inequality in democratic participation', Politics, 36, 1, 63-78.

Russell, M. and Gover, D. (2017) Legislation at Westminster: Parliamentary Actors and Influence in the Making of British Law, Oxford: Oxford University Press.

Saward, M. (2010) The Representative Claim, Oxford: Oxford University Press.

Saward, M. (2016) 'Fragments of equality in representative politics', Critical Review of International Social and Political Philosophy, 19, 3, 245-62.

Scottish Parliament (2015) Committee Engagement Strategy 2015-16, Edinburgh: Scottish Parliament. Scottish Parliamentary Corporate Body (2016) Public Engagement Strategy, Edinburgh: Scottish Parliament. 
Scottish Parliamentary Corporate Body (2017) Diversity and Inclusion Strategy, Edinburgh: Scottish Parliament.

Severs, E. (2010) 'Representation as claims-making: quid responsiveness?', Representation, 46, 4, 411-23.

Severs, E. (2012) 'Substantive representation through a claims-making lens: a strategy for the identification and analysis of substantive claims', Representation, 48, 2, 169-81.

Seyd, B., Curtice, J. and Rose, J. (2018) 'How might reform of the political system appeal to discontented citizens?', British Journal of Politics and International Relations, 20, 2, 263-84.

Social Exclusion Unit (2000) National Strategy for Neighbourhood Renewal: A Framework for Consultation, London: Cabinet Office.

Standards, Procedures and Public Appointments Committee (2018) Sexual Harassment and Inappropriate Conduct, Edinburgh: Scottish Parliamentary Corporate Body.

Thompson, L. (2014) 'Evidence taking under the microscope: how has oral evidence affected the scrutiny of legislation in House of Commons committees?', British Politics, 9, 4, 385-400.

Tisdall, K. (2014) Children Should be Seen and Heard?: Children and Young People's Participation in the UK, Basingstoke: Palgrave Macmillan.

Townsend, P. (1979) Poverty in the United Kingdom, Harmondsworth: Penguin.

Weldon, L. (2002) 'Beyond bodies: institutional sources of representation for women in democratic policymaking', Journal of Politics, 64, 4, 1153-74.

White, H. (2009) Parliamentary Scrutiny of Government, London: Institute for Government.

White, H. (2015) Select Committees Under Scrutiny: The Impact of Parliamentary Committee Inquiries on Government, London: Institute for Government.

Whiteley, P. (2012) Political Participation in Britain: The Decline and Renewal of Civic Culture, Basingstoke: Palgrave Macmillan.

Williams (1989) Social Policy: A Critical Introduction, Cambridge: Polity. 